\title{
Contact and Community: The Role of Social Interactions for a Political Identity
}

\begin{abstract}
Can social interaction contribute to a sense of community that transcends national borders? This question was initially raised by Deutsch (1953) and revived by Fligstein (2008). My analysis makes two contributions to this literature. First, insights from social psychology are applied to specify the microfoundations for why contact across group boundaries can be related to a collective identity. Second, a new threewave panel data set is used to examine the relationship empirically. The sample includes almost 1500 students at 38 German universities. The results show that social interaction contributes to a European identity, but that it is in particular contact with other international students rather than contact with hosts that fosters it most effectively. The data also reveal that contact has a more profound impact on individuals with a weak European identity to begin with. Finally, the change I find is stable after students return to their home institutions.
\end{abstract}

Key Words: Contact Hypothesis, Common In-Group Identity Model, European Identity, Erasmus, Panel Study

\section{Acknowledgements:}

I want thank Pamela Conover, Liesbet Hooghe, Hanna Kleider, Gary Marks, Thomas Risse, Emmanuel Sigalas as well as the anonymous reviewers for their thoughtful comments and suggestions. I gratefully acknowledge financial support from the Center for European Studies at the University of North Carolina at Chapel Hill, from the ERC project "Causes and Consequences of Multilevel Governance" (Grant \#249543), and from the Research College "The Transformative Power of Europe" at Freie Universitaet Berlin. I also want to thank the Erasmus coordinators at 38 German universities, who were kind enough to forward my survey to their students. All remaining errors are my own.

\section{Author:}

Florian Stoeckel, PhD

European University Institute

Via dei Roccettini 9

50014 San Domenico di Fiesole, Italien

florian.stoeckel@gmail.com 


\section{Introduction}

Contact between individuals from diverse ethnic, racial and national backgrounds has long been thought of as a means to lessen prejudice and foster trust (Pettigrew and Tropp 2006). However, can social interaction among individuals from diverse national backgrounds also contribute to a sense of transnational political community? My study seeks to tackle this issue by examining interaction between students from diverse European Union (EU) member states and its contribution to the evolution of a collective political identity that transcends national boundaries.

Whether Europeans think of themselves only as citizens of their nation states or also as members of a larger political community is an important precondition for the legitimacy of the EU and the continued transfer of authority from the national to the supranational level (Fuchs and Klingemann 2011). Empirical studies have found a stark difference in support for European integration between citizens who hold a European identity alongside their national identity and those who identify exclusively with their nation (Hooghe and Marks 2005; McLaren 2007).

To explore the role that social interaction plays in a collective European identity, recent research has turned to the intra European student exchange program, Erasmus. 270.000 European students annually spend time at another European university, thereby creating ample opportunities for intergroup contact. Yet, existing studies of Erasmus have produced surprisingly inconclusive results. Although cross sectional studies show that contact fosters a collective European identity (King and Ruiz-Gelices 2003; Fligstein 2008; Kuhn 2011; Mitchell 2012), prominent panel studies of intra European exchange students show often-cited null effects (Sigalas 2010; Wilson 2011). These mixed results stand in stark contrast with study abroad programs in other contexts, which have been found to have a profound impact on 
attitudes of participants towards their host country and its inhabitants as well as participants' own identities and personalities (Stangor et al. 1996; Schmitt et al. 2003; Sassenberg and Matschke 2010; Zimmermann and Neyer 2013).

My analysis is based on a new three-wave panel survey of Erasmus students. The survey has several advantages over previous Erasmus panels: a larger number of respondents, a considerably longer period of time covered (18 months), and a sample from a country not previously studied. 1206 students at 38 German universities were surveyed before leaving their home institutions to study in another European country, shortly after they returned, and again after five months. The results provide good reasons to believe that social interaction among students from different European countries contributes to a collective European identity.

The study makes both a theoretical and an empirical contribution. First, the results from the panel survey show that exchange programs can lead to a transnational identity that is stable for at least some time after the contact situation. This calls into question earlier longitudinal studies, which did not register change in students' identities and that therefore cast doubt on the role of contact for a shared European identity. Second, drawing on the common in-group identity model and on research on study abroad experiences in social psychology, I develop a more refined theory on the mechanism by which social interaction leads to identity change. My model emphasizes that the mechanism through which contact shapes a shared identity rests on the diversity of the social network within which it takes place. I theorize that rather than mere contact with hosts, sharing experiences with peers from diverse national backgrounds is more effective in shaping a sense of transnational community. I conclude that the conditions under which intergroup contact happens is highly important to understand how social interaction shapes identities beyond student exchanges. 


\section{Intergroup contact, studying abroad, and Europe's Erasmus program}

The contact hypothesis postulates that contact situations, which fulfill certain properties, foster mutual positive attitudes among individuals from different groups. According to Allport (1954) a successful reduction of intergroup biases requires the interactive situation to exhibit four properties: an equal status among those in contact, cooperative interdependence, common goals, and support of shared authorities, laws, or customs. Reviewing more than 500 studies from five decades of research on the contact hypothesis, Pettigrew and Tropp (2006) found overwhelming support for its empirical validity in numerous contexts.

Study abroad programs appear to create situations in which individuals from diverse backgrounds meet under very favorable conditions and at a point in time when individuals are more malleable than later in their lives. ${ }^{1}$ Based on American students who went to Germany, Stangor et al. (1996) find that a study abroad changes stereotypes and improves attitudes towards the host country. German students going to the US develop more positive attitudes towards US citizens because exchange students integrate the host society into their self-concept (Sassenberg and Matschke, 2010). At the same time, Schmitt et al. (2003) find that a rejection from hosts can tie a nationally diverse group of exchange students in the US together by creating a collective international student identity. Based on data from intra-European exchange students, Zimmermann and Neyer (2013) emphasize that study abroad experiences have a profound effect on personality characteristics - in particularly openness, agreeableness, and neuroticism - because they create a more diverse social network.

The Erasmus program allows European students to spend one or two terms at universities in other EU member states without additional fees and a chance to easily

\footnotetext{
${ }^{1}$ There are of course other mechanisms that contribute to a sense of transnational community, see for instance Fligstein (2008) on the role of cheap international travel and communication or Risse (2010) on incremental socialization processes through elite discourses.
} 
transfer credits. It creates opportunities for European students to meet peers from their host country and to interact intensely with a diverse set of other Erasmus program participants. The latter is fostered by the fact that Erasmus students often live together in "Erasmus bubbles" rather than with hosts (Cicchelli 2013). Yet, current research on Erasmus students shows surprisingly inconclusive results. Ex-post surveys of intraEuropean exchange students suggest that contact among Europeans prompts a European identity (King and Ruiz-Gelices 2003; Mitchell 2012). These studies do, however, share a common limitation. Because of the cross sectional nature of data, frequent social interaction with other Europeans might not in fact have triggered a stronger European identity, but could have existed previously.

In contrast to these ex-post studies, pre-post test designs cast doubt on the causal role of contact in a collective European identity. Wilson (2011) surveys students taking part in Erasmus before and after embarking on their trip abroad, but does not find any significant change. Sigalas (2010) also surveys students before and after going abroad. He shows that social interaction has a positive effect on identification with Europe (Sigalas 2010: 259.). Yet, when comparing data from before and after study abroad, Sigalas registers no change in identification with Europe among British students who study abroad. These findings are all the more surprising when compared with the evidence for contact effects from the above mentioned research on other study abroad experiences.

\section{How interaction can shape a notion of community}

Previous research on the effects of social interactions among European students rests on contact theory and its implications. Contact theory explains how positive interactions can reduce intergroup biases. Yet, it does not describe why social 
interaction might contribute to the emergence of a collective identity. To develop a more precise understanding of the mechanism and conditions under which contact can be expected to generate a transnational identity I rely on the common in-group identity model (CIIM, Gaertner et al. 1996; Gaertner and Dovidio 2000). The CIIM is based on the notion that individuals can think of themselves as members of smaller and more exclusive subgroups, or, alternatively, as members of larger and more encompassing (superordinate) groups. The CIIM suggests that the processes that reduce intergroup biases in contact situations are in fact stimuli for individuals from different groups to see themselves as a more encompassing single group. On the cognitive side, contact involves learning about the other subgroup, which undermines prejudice and enhances intercultural understanding. On the affective side, social interaction across groups reduces anxiety, fosters familiarity, and creates empathy with individuals previously perceived as out-group. Hence, contact decreases the perceived distance between subgroups and fosters the notion of belonging to a more comprehensive community. These processes are facilitated when a superordinate identity category is available that subsumes subgroup identities (Gaertner and Dovidio 2000).

The Erasmus program creates an ideal contact situation, because students have an equal status and the opportunity to form friendships across group boundaries. Following the CIIM, I understand national identities as subgroup identities. A collective European identity provides a superordinate identity category (Mols and Weber 2013), which should facilitate the perception of students to belong to a common in-group. Within this context, contact should give tangible content to what it means to be "European", turning it from an "imagined community" to a relevant identification category (Anderson 1991; Risse 2010). Therefore, intergroup contact 
should make a shared European identity more continuously accessible, which I hypothesize will manifest itself empirically in a more pronounced European identity.

Earlier studies in political science did not take into account that the type of social network that individuals interact with may have implications for whether they develop a shared European identity (King and Ruiz-Gelices 2003; Wilson 2011; Kuhn 2012). Work on the effects of study abroad experiences on personality traits in social psychology emphasizes that the acquisition of new and internationally diverse social relationships during the study abroad is the mechanism that drives change in students' openness and agreeableness (Zimmermann and Neyer 2013). I therefore argue that the type of social relationships students engage in also matters for developing a European identity. Hence, I differentiate between two specific types of social networks. While some students might interact primarily with individuals of their host country when abroad, others interact primarily with individuals from a diverse set of European countries. When students interact with peers who are also on study abroad, they are in touch with individuals sharing the same experience. I expect this to facilitate perceiving each other as members of a common in-group more than the contact situation between study abroad students and their hosts. A nationally diverse set of peers should create a particularly heterogeneous network of new friends. Being part of a group of individuals from different European countries reflects more accurately the diversity of the EU. Hence, my second hypothesis is that contact with a diverse set of individuals from different European countries fosters a European identity more directly than interaction between study abroad students and hosts.

My third expectation focuses on the extent to which individuals already have a pronounced European identity before entering a contact situation. I hypothesize transnational social interaction to have a stronger effect on individuals for whom a 
European identity is a comparably less important part of their self before going abroad. Previous findings suggest that the effectiveness of contact depends not only on external conditions, but also on the configuration of the political identity with which individuals enter the contact situation. Kuhn (2012) expects a ceiling effect, whereby individuals who already have a strong European identity may not be affected by study abroad. Transnational social interaction should be more formative for individuals who do not already have friends in other European countries and who lack intense contact with other Europeans. For them, the concept of a European identity previously abstract or meaningless - may become a more relevant, tangible, and meaningful identity in the context of new social interaction with individuals from other countries.

Finally, I have an expectation on the stability of the identity change. Transnational interaction might contribute only to euphoria about cosmopolitanism. If this were the case, self-identification as European would vanish shortly after the contact situation. However, the concept of a European identity is not created ad hoc. Instead, it is a shared group membership that exists outside of the contact situation. Gaertner and Dovidio (2000) argue that contact can shape a common in-groups ad hoc, e.g. based on common goals, but these in-group identities tend to be less meaningful outside of the contact situation. I assume that social interaction attaches a very personal meaning to the concept of a European identity, for instance through a more diverse network of friends. Therefore, my last hypothesis is that identity change is stable for at least some time after students' return. 


\section{Method: Research Design, Data, and Measurement}

The data come from a three-wave panel survey of German students who traveled to study in another European country, most of them using the so-called Erasmus program. I also collected data for a control group of students who did not participate in a study abroad program during the same period. ${ }^{2}$ The first wave took place in July and August 2010, before individuals in the study abroad group left their home institution. Participants were contacted again in May 2011 for the second wave of the survey. At this point, two thirds of the study abroad group had returned, while one third of the participants continued for a second term. All students were contacted in November 2011, when all participants had returned. This wave followed about half a year after the return of students who went abroad for one term. Respondents went to 24 of the 27 member states of the EU (see appendix, Table A1).

\section{$<$ Figure $1>$}

My European identity measure is inspired by Sigalas (2010) and based on five questions, two tapping cognitive issues and three gauging affective matters: the frequency with which someone thinks of herself as a European citizen; to what extent someone thinks they have something in common with other Europeans; attachment to Europe as a general measure of affection; pride in being a European; and perceived closeness to other Europeans (appendix, Table A15). All scales run from zero to six and are merged into an additive index (Cronbach's alpha=.79). An additive index has the appeal that units are more intuitively meaningful than those of a factor solution. This choice does not affect the substantive results.

\footnotetext{
${ }^{2}$ Thirty-eight higher education institutions forwarded my survey invitation to their students. I contacted professors of large lecture classes at German universities to collect data for the control group.
} 
I also gauge students' interaction with other international students and interaction with students from the host country. Interaction with each group is measured using three question items: socializing with the respective group generally, conversations involving personal problems, and discussing academic problems. The three items are merged into additive indices, namely one for contact with internationals (Cronbach's alpha $=0.91)$ and another for contact with hosts (Cronbach's alpha $=0.81){ }^{3}$

In order to assess the effect of social interaction on identity change in a regression analysis I control for a number of confounding factors. I account for the fact that a respondents' adjustment abroad could affect the dependent variable. For instance, an individual who finds it difficult to adapt abroad might not develop a stronger European identity. I control for respondents' level of homesickness as well as overall satisfaction with the study abroad program. Sigalas (2010) notes that a multicultural background might also have an effect on the extent to which social interaction abroad leaves an imprint on identity. Therefore, I include variables measuring a respondents' foreign language competence, frequency of traveling abroad, whether someone has previously lived abroad, and whether or not a student's parents have the same nationality. I also control for age and gender.

Students in the experimental and control group are broadly similar (see appendix, Table A2). I use a logistic regression to analyze if any characteristics predict group membership. ${ }^{4}$ Accordingly, students in the study abroad group traveled

\footnotetext{
${ }^{3}$ Data on students' amount of contact with internationals and hosts in the regression model comes from the survey answered after their return. However, ex-post reports might be biased. I conduct a robustness check by analyzing if the results hold when data on contact comes from reports given while abroad. The group of students staying abroad for two terms provides me with this opportunity. This analysis yields similar results in all substantively important respects (Table A17; Figures A1 and A2).
} 
more frequently within the past 12 months, they have greater language skills, and they are younger. Students in the experimental group have more contact with international students than those in the control group to begin with, but this difference does not predict group membership. What is more, this difference does not induce a bias, because study abroad students with less contact to internationals at the outset show a similar identity change than those with high initial levels of contact with international students. $^{5}$

I additionally account for the possibility that cultural openness might in part explain why contact is related to identity change by using information on reasons that students give for their study abroad. My survey offers ten motivations, as well as an open field, and respondents could select as many as three of these simultaneously (see appendix, Table A16). Most students go abroad for a combination of reasons. A smaller subset of students - about $14 \%$ - is going abroad only for job-related and other personal reasons, rather than because of their cultural openness. I use this difference to get a handle on whether cultural openness is a substantively meaningful driver for identity change. I include a dummy variable in the regression analysis that equals one if respondents did not mention any cosmopolitan reason as motivation for their study abroad.

Panel attrition leads to a loss of participants over the course of the study. 1206 students went abroad during the course of the panel and are thus the experimental group. 291 students stayed in Germany and make up the control group. Panel attrition

\footnotetext{
${ }^{4}$ The dependent variable is one for respondents in the control group and zero for those in the experimental group. The regression in Table A3 tests if any of the characteristics shown in Table A2 predict group membership.

${ }^{5}$ There is a significant difference in levels of contact with internationals between study abroad students and control group, $\mathrm{t}(872)=1.98, \mathrm{p}=.05$ (two tailed). A robustness check with students in the study abroad group who have a below-average level of contact with internationals reveals a significant increase in European identity scores among one term study abroad students $(\mathrm{t}(319)=4.15, \mathrm{p}<.001$ (two tailed), $\mathrm{d}=.18$ ) as well as among students staying two terms abroad $(\mathrm{t}(84)=5.16, \mathrm{p}<.001$ (two tailed), $\mathrm{d}=.48$ ).
} 
in the study abroad group amounts to 39 percent between the first and second wave, and another 29 percent between the second and the third wave (appendix, Table A4). While these figures reflect a non-negligible loss, the rate is comparable to those presented by other authors with similar designs (Sigalas 2010, Wilson 2011). Panel attrition does not seem to induce a grave bias. I run a logistics regression where dropping out $(=1)$ and staying $(=0)$ are the outcomes, and the characteristics shown in Table A2 are the independent variables. None of these variables are significant and the model fit is poor (Pseudo R2=0.01), indicating that panel attrition does not seriously impair the results (see appendix, Tables A5 and A6).

\section{The Malleability of Identities}

The results reveal that studying in another European country is related to a significant strengthening of a European identity. The European identity index increases from $\mathrm{M}=3.77$ to $\mathrm{M}=3.91$ for students who study one term abroad, $\mathrm{t}(555)=4.48, \mathrm{p}<.00$ (two tailed), $\mathrm{d}=.15$. The European identity score changes from $\mathrm{M}=3.87$ to $\mathrm{M}=4.12$ for students who went abroad for two terms, $\mathrm{t}(167)=4.28, \mathrm{p}<.00$ (two tailed), $d=.29$. Identification with Europe among students in the control group does not change over the period of the three waves of the panel, $\mathrm{t}(98)=0.74, \mathrm{p}=.46$ (two tailed), $d=.06$. This pattern confirms hypothesis 1 .

In a first robustness check, I re-analyze the data using a repeated measures mixed model. Rather than analyzing change in European identity scores of individuals in the study abroad groups and control group separately, as I have done above, the repeated measures model allows me to test if both groups exhibit a different rate of change in European identity scores over time. Here I use the logic of multilevel modeling to analyze panel data: measurements from different time points are nested 
within individuals (Rabe-Hesketh and Skrondal 2008). The result corroborates that European identity scores increase among Erasmus students and remain unchanged in the control group (Tables A9 and A11). A significant interaction between group and time further confirms the different development of European identity scores in control group and study abroad groups over the course of the panel (one term abroad: $b=.23$, $\mathrm{SE}=.07, \mathrm{p}=.001$; two terms abroad: $\mathrm{b}=.19, \mathrm{SE}=.09, \mathrm{p}=.04$; Tables $\mathrm{A} 8$ and A10). However, a repeated measures mixed model does not deal with covariate imbalances between treatment and control group that could bias the results. To this end I conduct a matching analysis as a second robustness check (for an application in Political Psychology, see Dinesen 2012). Matching takes imbalances between experimental and control group into account when estimating "treatment effects" in observational studies. It is one a way to get a handle on the potentially higher propensity of Erasmus students to develop a European identity when abroad than individuals in the control group. Yet, matching can merely approximate the logic of an experiment since it is a post-treatment adjustment. One of its limitations is that the balance of treatment and control groups can only be achieved on observed covariates. Using propensity score matching I find additional support for the expectation that an intra European study abroad can contribute to a collective European identity. Propensity score matching estimates an average effect of studying abroad of $b=.26(\mathrm{SE}=.13, \mathrm{p}=.035)$ based on a comparison of one term study abroad students and individuals in the control group; it reveals an average effect of studying abroad of $b=.23$ (SE .18, $p=.21)$ for students who went away for two terms. ${ }^{6}$

\footnotetext{
${ }^{6}$ Matching of two term study abroad students with students in the control group leads to an exclusion of 54 individuals, which leads to this tests' more limited statistical power (see Tables A12 and A13 for full details).
} 


\section{The Effect of Contact with an International Community}

I would like to further investigate if social interactions do indeed drive identity change using a regression analysis. The dependent variable is respondents' European identity score after their return. ${ }^{7}$ I include respondents' European identity score before going abroad as independent variable. Therefore, coefficients of all other independent variables reflect their effect on identity change over time. ${ }^{8}$

\section{< Table 1 here $>$}

< Figure 2 here>

< Figure 3 here $>$

The results support a link between social interaction and identity change (Table 1). Social interaction with other international students has a statistically significant effect on identity change $(b=.05, \mathrm{SE}=.01, \mathrm{p}<.001)$. Interaction with students from the host country does not have a significant effect $(b=.03, \mathrm{SE}=.02$, $\mathrm{p}=.24)$. Model 2 shows that contact with international students remains a significant predictor for identity change when applying controls. Among the control variables only frequency of travel has a significant effect on identity change. Importantly, the dummy variable for the small share of respondents for whom cultural motivations are

\footnotetext{
${ }^{7}$ I pool all students who went abroad. Data on students' European identity after studying abroad comes from wave 2 for those who went abroad for one term and from wave 3 for those who went abroad for two terms.

${ }^{8}$ There is a debate about whether using post-test values (with lagged dependent variable) or change between two time points is a more appropriate modeling strategy (e.g. Allison 1990, Finkel 1995). Both approaches lead to similar results here. However, a model with post-test values and a lagged dependent variable accounts more accurately for change that might be related to initial levels (Finkel 1995: 6), which is what I expect theoretically and find empirically (hypothesis 3).
} 
not one of the reasons for their study abroad is not significant. Apparently, students who go abroad for personal or professional reasons, rather than their cultural openness, are no less likely to develop a more pronounced European identity. In sum, the results provide additional support for hypothesis one on the relationship between contact across group boundaries and a collective identity. Yet, only interaction with a diverse group of international students, which mirror more faithfully the diversity implied by a shared European identity, has a significant effect on identification with Europe. This supports my second hypothesis.

In hypothesis three, I expect that social interaction has a greater effect on individuals with a weaker identification with Europe before going abroad, and test this through interacting initial European identity with both types of contact (Model 3). Marginal effects plots visualize the substantive effect (Figures 2 and 3). Social interaction with other international students has a more pronounced effect the weaker an individuals' identification with Europe before going abroad. Social interaction has no statistically significant effect when identification with Europe is high at the outset. These results confirm hypothesis three.

\section{Stability of Identity Change}

Is the effect of social interaction a short-lived European identity spark attributable to the excitement of an adventurous journey? The data suggest that studying abroad leaves an imprint that is stable for some time after the study abroad. The second survey wave took place at a point in time when one term study abroad students returned. Wave three followed after another five months, which these respondents spend at their home institutions. Based on these students I test if the more pronounced European identity that individuals developed abroad is stable some 
months after their return. The result is that there is no drop in the European identity index between wave two and three, $\mathrm{t}(256)=0.47, \mathrm{p}=.64$ (two-tailed), $\mathrm{d}=.02$, confirming hypothesis four.

\section{Discussion}

My findings demonstrate that social interaction across individuals with different national backgrounds helps build a shared transnational identity, a result not thrown up by previous research on students (Sigalas 2010; Wilson 2011) and elites (Hooghe 2005; Kassim et al., 2013). This study also extends our understanding of the precise conditions under which social interaction contributes to a collective identity. Building on contact theory and the common in-group identity model, I argue that the intergroup contact situation must fulfill certain properties to contribute to a shared identity, for example individuals from different groups need to perceive each other as hierarchically equal and be in a position to form friendships across group boundaries. Furthermore, my theoretical model highlights an aspect unrecognized by previous research, namely that the type of social network while abroad matters more than quantity of social interactions: for individuals to embrace a European identity they need to interact with a nationally diverse set of people with whom they share experiences, rather than only with individuals from a host country. Under these conditions, social interaction can attach a personal meaning to a transnational collective identity. Indeed my findings suggest that only interaction of study abroad students with other international students contributes to a European identity, while contact with hosts does not have the same effect.

Like other panel studies on student interaction, respondents are not randomly assigned to treatment and control condition. It might be reasonable to expect that 
participants already see themselves as Europeans to begin with, which might be a reason for them to study abroad in the first place. If this were the case, this would bias the study against finding an effect of social interaction. In reality, there is considerable variation with regard to participants' identification with Europe at the outset and there are substantial differences in their reasons for going abroad. I do find that social interaction is less effective among individuals with a strong European identity to begin with. However, I can also show precisely that those with a weak European identity appear to be most affected by social interaction abroad.

The results also raise puzzles that deserve further investigation. My theoretical framework puts much emphasis on the conditions needed for contact to translate into a European identity, but much social interaction among Europeans does not fulfill these conditions. Tourists only travel for short periods to other European countries, only rarely allowing them to have intense interaction. Blue-collar workers might stay for longer periods. Yet, those who hired them might treat these workers as inferior in status. This hierarchical difference could be critical for how migrating workers experience an integrated Europe. Future research could examine whether social interaction among a diverse set of individuals contributes to a collective identity if the contact situation is less ideal than that faced by exchange students. 


\section{References}

Allison, P. D. (1990). Change scores as dependent variables in regression analysis. Sociological Methodology, 20, 93-114.

Allport, G. W. (1954). The nature of prejudice. Reading: Addison-Wesley.

Anderson, B. (1991). Imagined communities: Reflections on the origin and Spread of nationalism. London: Verso.

Cicchelli, V. (2013). The Cosmopolitan 'Bildung'of Erasmus Students' Going Abroad. In Y. Hébert and A. Abdi (Eds.), Critical Perspectives on International Education (pp. 205-208). Rotterdam: SensePublishers.

Deutsch, K. W. (1953). Nationalism and social communication. Cambridge: MIT Press.

Dinesen, P. (2012). Does Generalized (Dis)Trust Travel? Examining the Impact of Cultural Heritage and Destination-Country Environment on Trust of Immigrants. Political Psychology, 33, 495-511.

Finkel, S. E. (1995). Causal analysis with panel data (Sage University Paper Series on Quantitative Applications in the Social Sciences, 07-105). Thousand Oaks, CA: Sage.

Fligstein, N. (2008). Euroclash: The EU, European identity, and the future of Europe. Oxford: Oxford University Press.

Fuchs, D. and H.-D. Klingemann (Eds.) (2011). Cultural diversity, European identity and the legitimacy of the EU. Cheltenham: Edward Elgar Publishing.

Gaertner, S. L. and J. F. Dovidio. (2000). Reducing intergroup bias: The common ingroup identity model. Philadelphia: Psychology Press.

Gaertner, S., J. Dovidio, B. Bachman (1996). Revisiting the contact hypothesis: the induction of a common ingroup identity. International Journal of Intercultural Relations, 20, 271-290.

Hooghe, L. (2005). Several roads lead to international norms, but few via international socialization. A case study of the European Commission. International Organization, 59, 861-898.

Hooghe, L. and G. W. Marks (2005). Calculation, community and cues. European Union Politics, 6, 419-43.

Kassim, H., J. Peterson, M. Bauer, S. Connolly, R. Dehousse, L. Hooghe, and A. Thompson (2013). The European Commission of the twenty-first century. Oxford: Oxford University Press.

King, R. and E. Ruiz-Gelices (2003). International student migration and the 
European 'year abroad': Effects on European identity and subsequent migration behaviour. International Journal of Population Geography, 9, 229-52.

Kuhn, T. (2011). Individual transnationalism, globalisation and euroscepticism: An empirical test of Deutsch's transactionalist theory. European Journal of Political Research, 50, 811-37.

Kuhn, T. (2012). Why educational exchange programmes miss their Mark: Crossborder mobility, education and European identity. Journal of Common Market Studies, 50, 994-1010.

McLaren, L. (2007). Explaining mass-level Euroscepticism: Identity, interests, and institutional distrust. Acta Politica, 42, 233-51.

Mitchell, K. (2012). Student mobility and European identity: Erasmus study as a civic experience? Journal of Contemporary European Research, 8, 490-518.

Mols, F. and M. Weber (2013). Laying sound foundations for social identity theoryinspired European Union attitude research: Beyond attachment and deeply rooted identities. Journal of Common Market Studies, 51, 505-521.

Pettigrew, T. F., and L. R. Tropp (2006). A meta-analytic test of intergroup contact theory. Interpersonal Relations and Group Processes, 90, 751-83.

Rabe-Hesketh, S., and A. Skrondal (2008). Multilevel and longitudinal modelling using Stata. College Station: STATA Press.

Risse, T. (2010). A community of Europeans? Ithaca: Cornell University Press. Sassenberg, K. and C. Matschke (2010). The impact of exchange programs on the integration of the hostgroup into the self-concept. European Journal of Social Psychology, 40, 148-159.

Schmitt, M., R. Spears, N. Branscombe (2003). Constructing minority group identity out of shared rejection: The case of international students. European Journal of Social Psychology, 33, 1-12.

Sigalas, E. (2010). Cross-border mobility and European identity: The effectiveness of intergroup contact during the ERASMUS year abroad. European Union Politics, 11, $241-65$.

Stangor, C., K. Jonas, W. Stroebe and M. Hewstone (1996). Influence of student exchange on national stereotypes, attitudes and perceived group variability. European Journal of Social Psychology, 26, 663-675.

Wilson, I. (2011). What should we expect of Erasmus generations? Journal of Common Market Studies, 49, 1113-40.

Zimmermann, J. and F. J. Neyer (2013). Do we become a different person when hitting the road? Personality and development of sojourners. Journal of Personality and Social Psychology, 105, 515-530. 
Table 1. Social interaction and European Identity

\begin{tabular}{|c|c|c|c|}
\hline & Model 1 & Model 2 & Model 3 \\
\hline Contact w/ international students & $\begin{array}{l}0.05^{\pi \times \pi} \\
(0.01)\end{array}$ & $\begin{array}{l}0.04^{\pi \pi} \\
(0.01)\end{array}$ & $\begin{array}{l}0.14^{\pi} \\
0.06\end{array}$ \\
\hline Contact w/ internationals*pre-EU ID & & & $\begin{array}{c}-0.03 \\
(0.02)\end{array}$ \\
\hline Contact w/ host country students & $\begin{array}{c}0.03 \\
(0.02)\end{array}$ & $\begin{array}{c}0.02 \\
(0.02)\end{array}$ & $\begin{array}{c}0.08 \\
(0.09)\end{array}$ \\
\hline Contact w/ hosts* pre-EU ID & & & $\begin{array}{c}-0.01 \\
(0.02)\end{array}$ \\
\hline Satisfaction w/ study abroad & & $\begin{array}{c}0.04 \\
(0.03)\end{array}$ & $\begin{array}{c}0.04 \\
(0.03)\end{array}$ \\
\hline Ease of adaption & & $\begin{array}{c}0.02 \\
(0.02)\end{array}$ & $\begin{array}{c}0.02 \\
(0.02)\end{array}$ \\
\hline Home sickness & & $\begin{array}{l}-0.02 \\
(0.02)\end{array}$ & $\begin{array}{l}-0.02 \\
(0.02)\end{array}$ \\
\hline age & & $\begin{array}{c}-0.01 \\
(0.01)\end{array}$ & $\begin{array}{c}-0.01 \\
(0.01)\end{array}$ \\
\hline $\operatorname{sex}$ & & $\begin{array}{c}0.04 \\
(0.06)\end{array}$ & $\begin{array}{c}0.04 \\
(0.06)\end{array}$ \\
\hline 2-term dummy (ref.: 1 term) & & $\begin{array}{c}0.09 \\
(0.06)\end{array}$ & $\begin{array}{c}0.09 \\
(0.06)\end{array}$ \\
\hline lived abroad & & $\begin{array}{l}-0.07 \\
(0.05)\end{array}$ & $\begin{array}{l}-0.07 \\
(0.05)\end{array}$ \\
\hline frequency of travelling & & $\begin{array}{l}0.08^{x *} \\
(0.03)\end{array}$ & $\begin{array}{l}0.08^{x *} \\
(0.03)\end{array}$ \\
\hline Foreign language competence & & $\begin{array}{c}-0.01 \\
(0.03)\end{array}$ & $\begin{array}{c}-0.01 \\
(0.03)\end{array}$ \\
\hline Parents' nationality & & $\begin{array}{c}0.17 \\
(0.10)\end{array}$ & $\begin{array}{c}0.16 \\
(0.10)\end{array}$ \\
\hline Non-cosmopolitan & & $\begin{array}{c}0.03 \\
(0.07)\end{array}$ & $\begin{array}{c}0.02 \\
(0.07)\end{array}$ \\
\hline European identity before going abroad $\left(Y_{\mathrm{t}-1}\right)$ & $\begin{array}{l}0.66^{\pi \pi \pi} \\
(.03)\end{array}$ & $\begin{array}{l}0.63^{\pi \times \pi} \\
(0.01)\end{array}$ & $\begin{array}{l}0.80^{\pi \pi x} \\
(0.09)\end{array}$ \\
\hline Constant & $\begin{array}{l}1.10^{\lambda \pi \pi} \\
(0.13)\end{array}$ & $\begin{array}{l}1.06^{x *} \\
(0.42)\end{array}$ & $\begin{array}{c}0.46 \\
(0.54)\end{array}$ \\
\hline Adjusted $\mathrm{R}^{2}$ & .47 & 0.48 & 0.48 \\
\hline$N$ & 715 & 704 & 704 \\
\hline
\end{tabular}


Figures

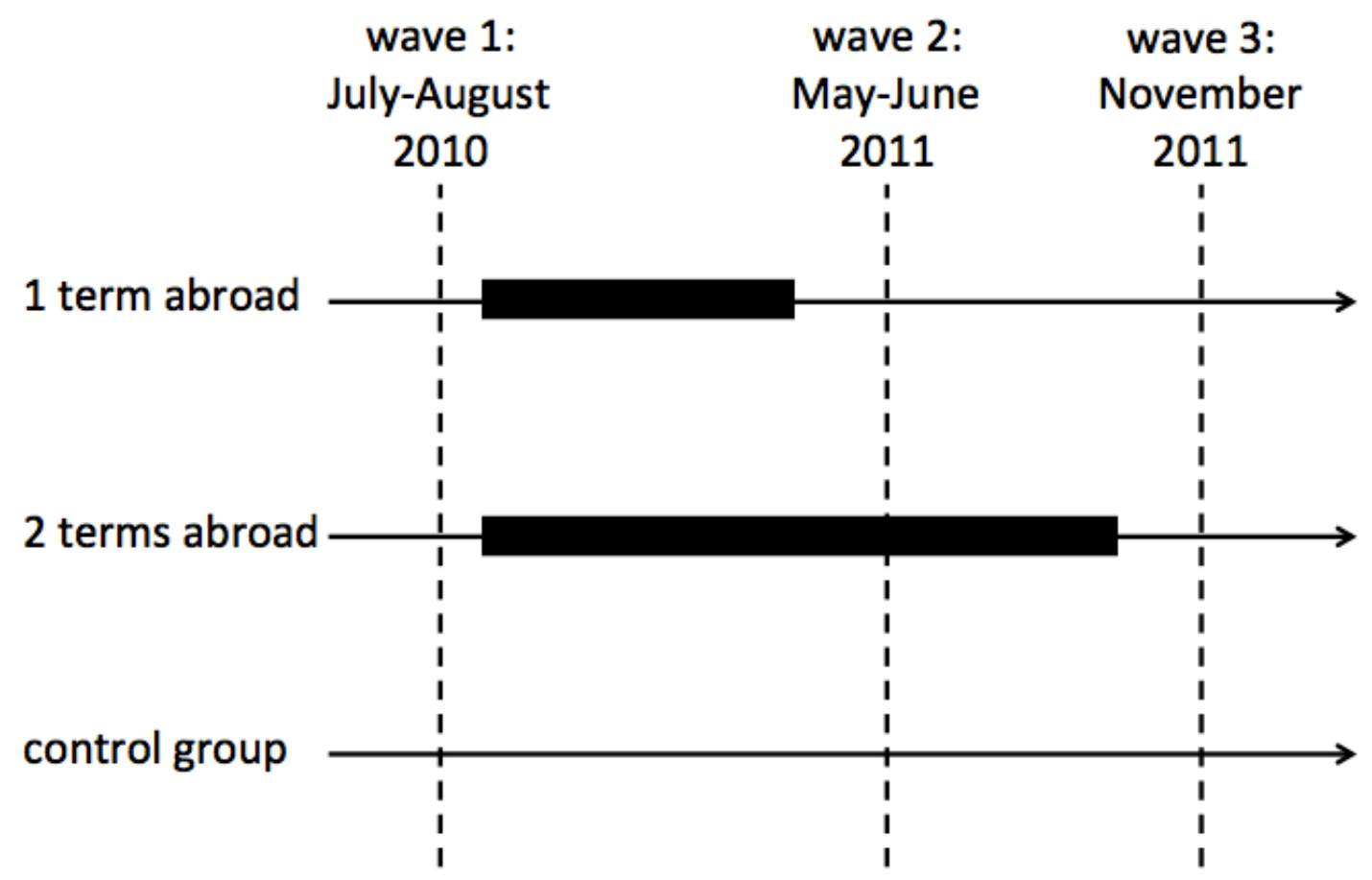

Figure 1. Research design and timing of survey waves. 


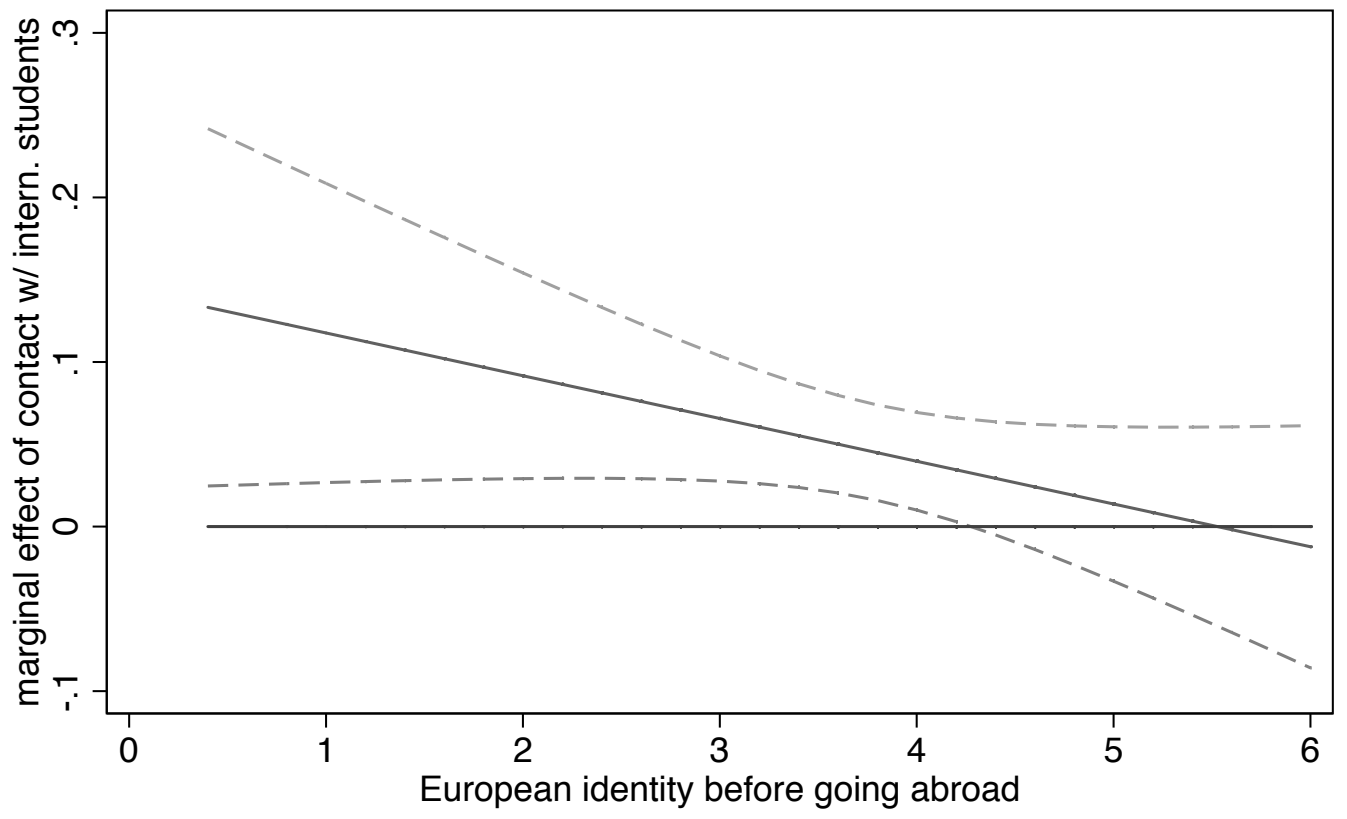

Figure 2. Marginal effect of contact with international students

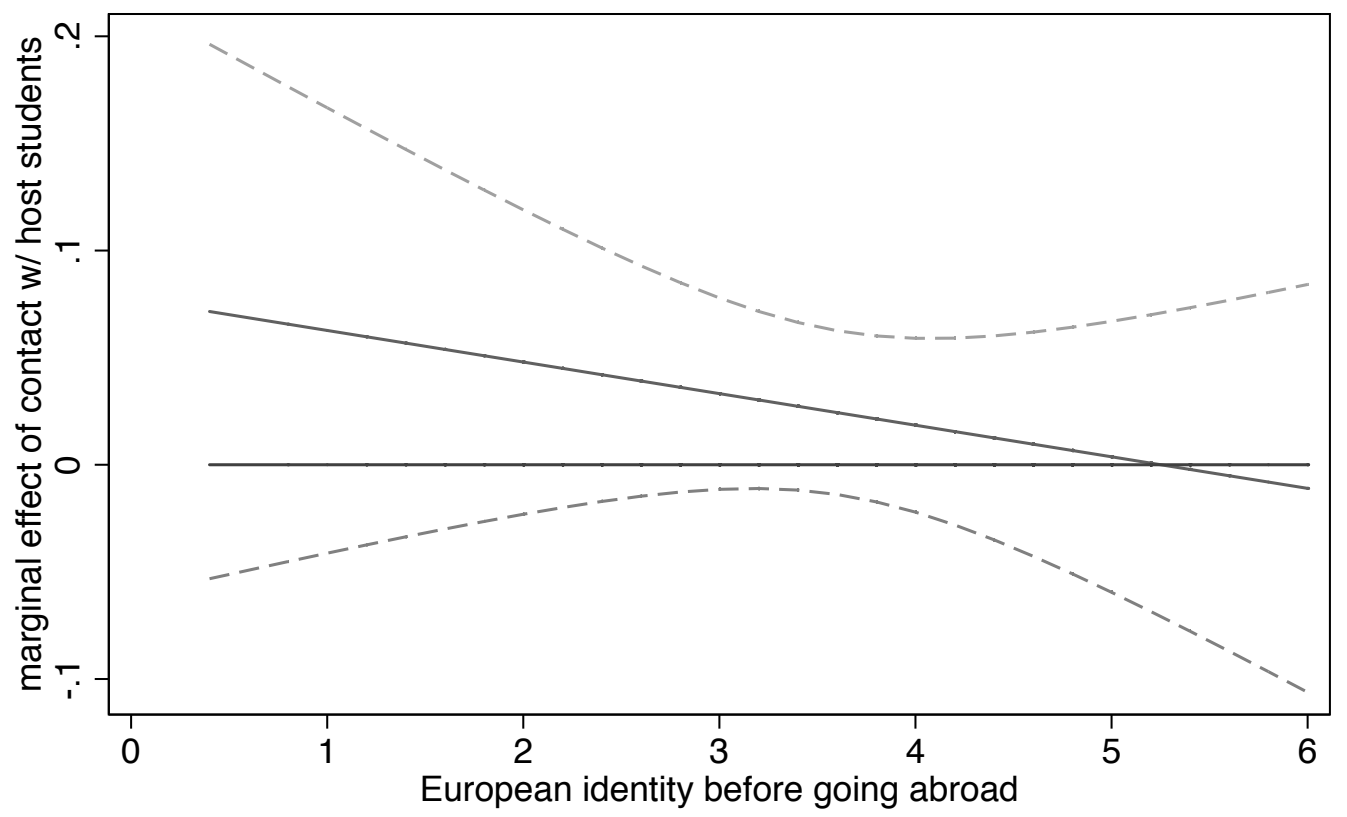

Figure 3. Marginal effect of contact with students from host country 
ONLINE APPENDIX

Table A1. Countries visited by participants of the panel study.

\begin{tabular}{|c|c|c|c|c|}
\hline \multirow[b]{2}{*}{ Country } & \multicolumn{2}{|c|}{1 term abroad } & \multicolumn{2}{|c|}{2 terms abroad } \\
\hline & $\mathrm{N}$ & Percent & $\mathrm{N}$ & Percent \\
\hline Austria & 4 & 0.71 & 4 & 2.33 \\
\hline Belgium & 9 & 1.59 & 1 & 0.58 \\
\hline Bulgaria & 2 & 0.35 & & \\
\hline Czech Republic & 7 & 1.24 & 4 & 2.33 \\
\hline Denmark & 23 & 4.06 & 4 & 2.33 \\
\hline Finland & 26 & 4.59 & 4 & 2.33 \\
\hline France & 117 & 20.67 & 33 & 19.19 \\
\hline Greece & 5 & 0.88 & 1 & 0.58 \\
\hline Hungary & 8 & 1.41 & 2 & 1.16 \\
\hline Ireland & 25 & 4.42 & 3 & 1.74 \\
\hline Italy & 34 & 6.01 & 20 & 11.63 \\
\hline Latvia & 4 & 0.71 & & \\
\hline Lithuania & 1 & 0.18 & & \\
\hline Luxemburg & 1 & 0.18 & & \\
\hline Malta & 1 & 0.18 & & \\
\hline Netherlands & 18 & 3.18 & 5 & 2.91 \\
\hline Poland & 11 & 1.94 & 3 & 1.74 \\
\hline Portugal & 9 & 1.59 & 4 & 2.33 \\
\hline Rumania & 1 & 0.18 & 1 & 0.58 \\
\hline Slovakia & 2 & 0.35 & & \\
\hline Slovenia & 1 & 0.18 & 1 & 0.58 \\
\hline Spain & 113 & 19.96 & 40 & 23.26 \\
\hline Sweden & 77 & 13.6 & 14 & 8.14 \\
\hline UK & 67 & 11.84 & 28 & 16.28 \\
\hline total & 566 & 100 & 172 & 100 \\
\hline
\end{tabular}


Table A2. Study abroad and control group

\begin{tabular}{|c|c|c|}
\hline & Study abroad group & Control group \\
\hline Age & $23.1(1.9)$ & $24.0(3.6)$ \\
\hline \multicolumn{3}{|l|}{ Gender } \\
\hline Female: & $66.5 \%$ & $61.7 \%$ \\
\hline Male: & $33.5 \%$ & $38.3 \%$ \\
\hline \multirow{2}{*}{\multicolumn{3}{|c|}{$\begin{array}{l}\text { Multicultural background } \\
\text { Parents nationality }\end{array}$}} \\
\hline Parents nationality: & & \\
\hline Same: & $93 \%$ & $98.0 \%$ \\
\hline Different: & $7.0 \%$ & $2.0 \%$ \\
\hline \multicolumn{3}{|l|}{ Foreign languages } \\
\hline Spoken & & \\
\hline 0 & $0 \%$ & $0.7 \%$ \\
\hline 1 & $22.1 \%$ & $44.3 \%$ \\
\hline 2 & $50.3 \%$ & $39.6 \%$ \\
\hline $2<$ & $27.6 \%$ & $15.4 \%$ \\
\hline \multicolumn{3}{|l|}{$\begin{array}{l}\text { Frequency of travelling abroad } \\
\text { in past } 12 \text { months }\end{array}$} \\
\hline Not at all & $0.6 \%$ & $2.7 \%$ \\
\hline 1-2 times & $5.0 \%$ & $18.8 \%$ \\
\hline 3-4 times & $18.0 \%$ & $30.2 \%$ \\
\hline 5-6 times & $25.7 \%$ & $21.5 \%$ \\
\hline 7 times or more & $50.8 \%$ & $26.9 \%$ \\
\hline \multicolumn{3}{|l|}{ Lived abroad } \\
\hline No: & $54.3 \%$ & $59.1 \%$ \\
\hline Yes: & $45.7 \%$ & $40.9 \%$ \\
\hline $\begin{array}{l}\text { Contact with international students } \\
\text { at wave } 1\end{array}$ & $2.1(1.5)$ & $1.82(1.4)$ \\
\hline \multicolumn{3}{|l|}{ Political background } \\
\hline GAL-TAN ideology & $3.2(2.0)$ & $2.9(1.7)$ \\
\hline Left-right ideology & $4.1(4.1)$ & $3.8(1.4)$ \\
\hline European identity index (low to high) & $3.8(0.9)$ & $3.6(0.9)$ \\
\hline $\mathrm{N}$ & 724 & 148 \\
\hline
\end{tabular}


Table A3. Study abroad and control group. Logistic regression

\begin{tabular}{|c|c|c|c|}
\hline & Coefficient & & Standard Error \\
\hline Age & 0.12 & ** & 0.04 \\
\hline Gender & 0.03 & & 0.22 \\
\hline \multicolumn{4}{|l|}{ Multicultural background } \\
\hline Parents nationality & & & \\
\hline (1=different) & -1.15 & & 0.62 \\
\hline Foreign languages & & & \\
\hline Spoken & -0.34 & ** & 0.14 \\
\hline Frequency travelling abroad & -0.59 & *** & 0.10 \\
\hline Lived abroad & 0.09 & & 0.11 \\
\hline $\begin{array}{l}\text { Contact with international } \\
\text { students at wave } 1\end{array}$ & -0.05 & & 0.07 \\
\hline \multicolumn{4}{|l|}{ Political background } \\
\hline GAL-TAN ideology & -0.06 & & 0.06 \\
\hline Left-right ideology & -0.14 & & 0.08 \\
\hline European identity index & 0.08 & & 0.12 \\
\hline constant & -1.55 & & 1.10 \\
\hline $\begin{array}{l}\mathrm{N} \\
\text { Pseudo-R2 }\end{array}$ & $\begin{array}{l}825 \\
0.11\end{array}$ & & \\
\hline
\end{tabular}


Table A4. Panel attrition

\begin{tabular}{lllll}
\hline & & Wave 1 & Wave 2 & Wave 3 \\
\hline Study abroad & $\mathrm{N}$ & 1206 & 738 & 530 \\
group & attrition in percent & & 38.8 & 29.2 \\
\multirow{2}{*}{ Control group } & $\mathrm{N}$ & 291 & 149 & 99 \\
& attrition in percent & & 49.8 & 33.6 \\
\hline total & $\mathrm{N}$ & 1497 & 887 & 629 \\
\hline
\end{tabular}


Table A5. Analysis of drop-outs (study abroad group). Logistic regression

\begin{tabular}{lcr}
\hline & Coefficient & $\begin{array}{r}\text { Standard } \\
\text { Error }\end{array}$ \\
\hline Age & 0.08 & 0.03 \\
Gender & 0.06 & 0.14 \\
Multicultural background & & \\
Parents nationality & & \\
(1=different) & 0.35 & 0.23 \\
Foreign languages & & 0.08 \\
Spoken & -0.07 & 0.07 \\
Frequency travelling abroad & 0.03 & 0.07 \\
Lived abroad & 0.08 & \\
Political background & & 0.04 \\
GAL-TAN ideology & -0.01 & 0.05 \\
Left-right ideology & 0.04 & 0.07 \\
European identity index & -0.04 & 0.90 \\
constant & $-2.62 * *$ & \\
\hline $\mathrm{N}$ & 1126 & \\
Pseudo-R2 & 0.01 & \\
\hline Note: $1=$ dropped out, $0=$ stayed in panel; $p<0.05$, & $p<0.01$, & $p<0.001$ \\
\end{tabular}


Table A6. Analysis of drop-outs (control group). Logistic regression

\begin{tabular}{|c|c|c|c|}
\hline & Coefficient & & Standard Error \\
\hline Age & 0.06 & & 0.04 \\
\hline Gender & 0.08 & & 0.28 \\
\hline $\begin{array}{l}\text { Multicultural backgrou } \\
\text { Parents nationality }\end{array}$ & & & \\
\hline $\begin{array}{l}\text { (1=different) } \\
\text { Foreign languages }\end{array}$ & 0.65 & & 0.81 \\
\hline Spoken & -0.40 & ** & 0.19 \\
\hline $\begin{array}{l}\text { Frequency } \\
\text { travelling abroad }\end{array}$ & -0.02 & & 0.13 \\
\hline $\begin{array}{l}\text { Lived abroad } \\
\text { (1=yes) }\end{array}$ & 0.17 & & 0.15 \\
\hline Political background & & & \\
\hline GAL-TAN ideology & 0.09 & & 0.08 \\
\hline Left-right ideology & 0.33 & ** & 0.11 \\
\hline European identity index & -0.14 & & 0.11 \\
\hline constant & -2.45 & & 1.17 \\
\hline $\begin{array}{l}\mathrm{N} \\
\text { Pseudo-R2 }\end{array}$ & $\begin{array}{l}269 \\
0.09\end{array}$ & & \\
\hline
\end{tabular}


Table A7. Paired t-test on European identity change.

\begin{tabular}{llll} 
& $\begin{array}{l}\text { Pre-test } \\
(\mathrm{SD})\end{array}$ & $\begin{array}{l}\text { Post-test } \\
(\mathrm{SD})\end{array}$ & $\begin{array}{l}\Delta \\
(\mathrm{SE})\end{array}$ \\
\hline Study abroad: & 3.77 & 3.91 & $0.14^{\text {** }}$ \\
1 term & $(.94)$ & $(.94)$ & $(.03)$ \\
$\mathrm{N}=556$ & & & \\
& & 4.12 & $0.25^{\text {** }}$ \\
Study abroad: & 3.87 & $(.86)$ & $(.06)$ \\
2 terms & $(.88)$ & & \\
$\mathrm{N}=168$ & & & \\
\hline
\end{tabular}

Wave $1 \quad$ Wave 2

\begin{tabular}{llll}
\hline Control & 3.62 & 3.52 & -0.09 \\
$\mathrm{~N}=149$ & $(.93)$ & $(1.04)$ & $(.06)$ \\
& & & \\
& Wave 1 & Wave 3 & \\
\hline Control & 3.59 & 3.64 & 0.05 \\
$\mathrm{~N}=99$ & $(.93)$ & $(.92)$ & $(.07)$ \\
\hline
\end{tabular}

${ }^{* * *} p<.001$, two tailed significance test, scale: 0-6, standard errors in parentheses 
Table A8. Repeated measures mixed model (1 term abroad), DV= European identity index

\begin{tabular}{|c|c|c|}
\hline & Coefficient & Standard Error \\
\hline Group effect & 0.15 & 0.09 \\
\hline Time effect & -0.10 & 0.06 \\
\hline \multicolumn{3}{|l|}{ Time by Group } \\
\hline & $0.23^{* *}$ & 0.07 \\
\hline constant & $3.62^{* * *}$ & 0.08 \\
\hline \multicolumn{3}{|c|}{ Random effects parameters } \\
\hline Var (constant) & $0.62^{* * *}$ & 0.04 \\
\hline Var (residual) & $0.28^{* * *}$ & 0.01 \\
\hline $\mathrm{N}$ (observations) & 1410 & \\
\hline$N$ (groups) & 705 & \\
\hline Log-likelihood & -1706.1527 & \\
\hline
\end{tabular}


Table A9. Post hoc estimation (following repeated measures mixed model): test for significance of change between wave 1 and 2 by group based on mixed model shown above ("delta method"; 1 term abroad students)

Control group

Wave

2 vs. 1

Study abroad

group

Wave

2 vs. 1

$0.14^{* * *}$

0.03


Table A10. Repeated measures mixed model ( 2 term abroad students), DV= European identity index

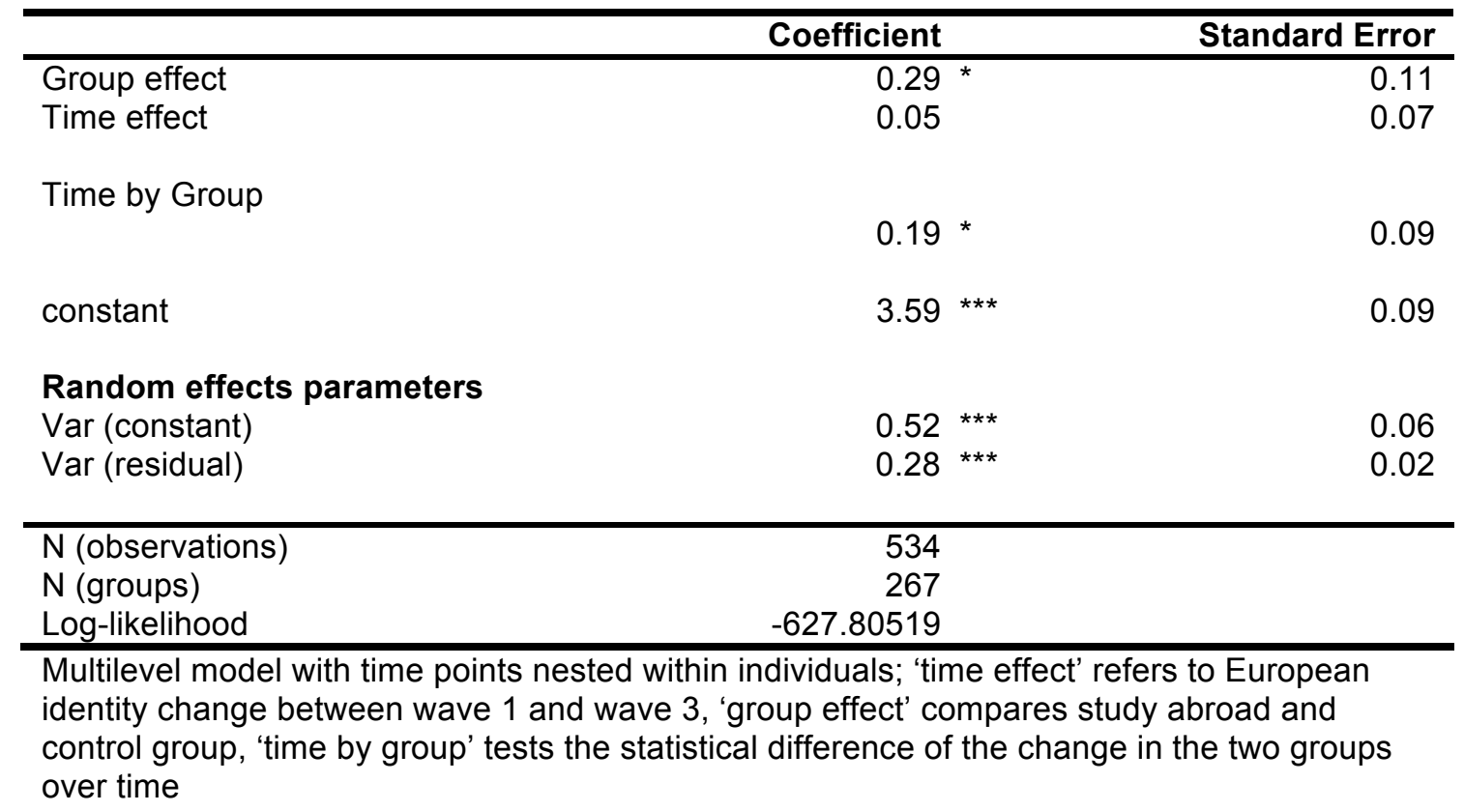


Table A11. Post hoc estimation (following repeated measures mixed model): test for significance of change between wave 1 and 3 by group based on mixed model shown above ("delta method"; 2 term abroad students)

Control group

Wave

3 vs. 1

Study abroad

group

Wave

3 vs. 1 
Table A12. Sample comparison for matching analysis (1 terms study abroad \& control)

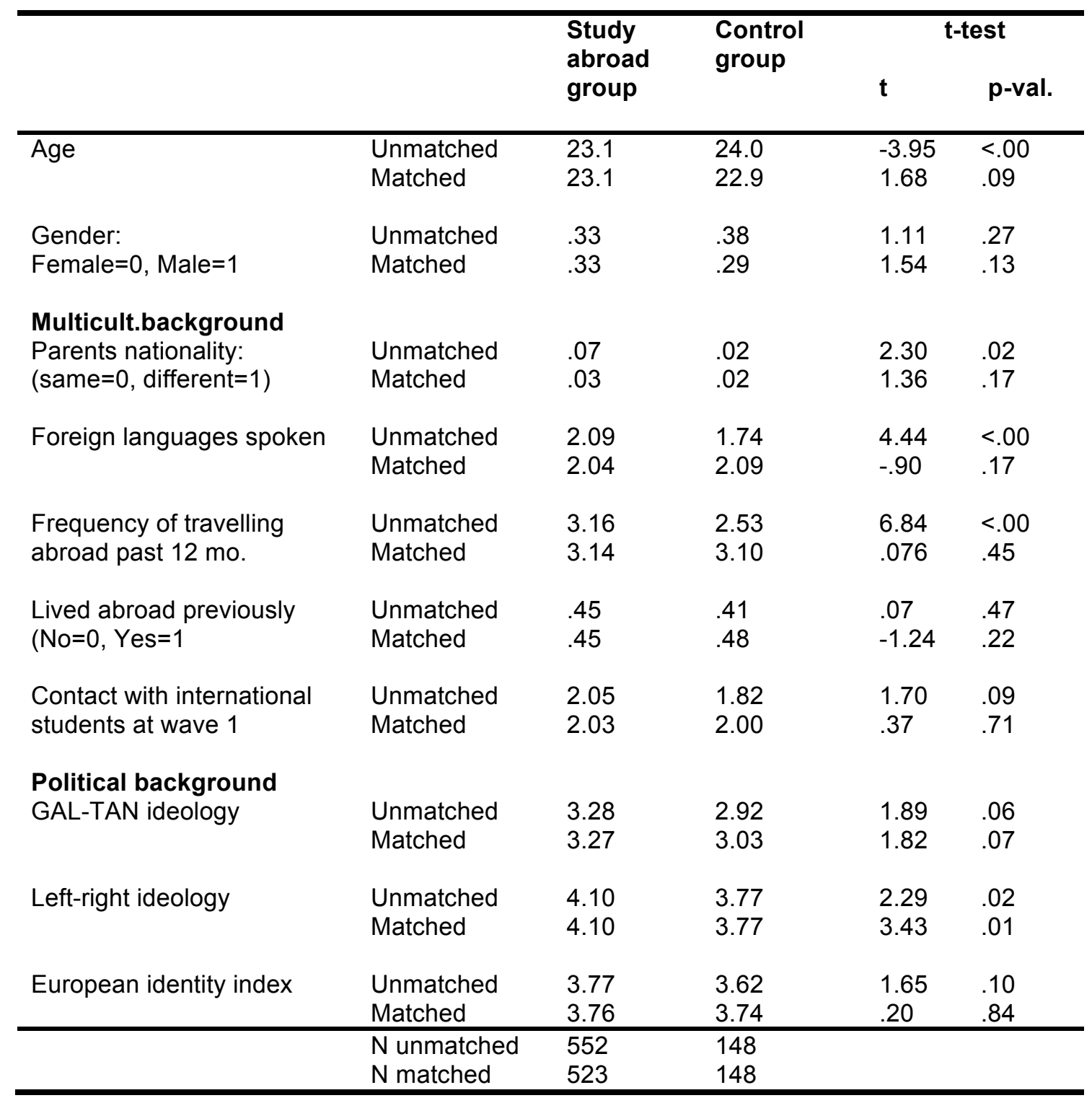

Note: (1) Non-parametric combinations (NPC) testing led to a rejection of the sharp null hypothesis of no difference between study abroad and control group ( $\mathrm{p}<.00$; conducted in R using the NPC function programmed by Caughey, Dafoe, and Seawright, 2014). I conducted a matching analysis to check the robustness of results when controlling for imbalances between treatment and control group. (2) The matching analysis that produced the samples above was conducted based on one term study abroad group and control group. 
Table A13. Sample comparison for matching analysis (2 term study abroad \& control)

\begin{tabular}{|c|c|c|c|c|c|}
\hline & & \multirow{2}{*}{$\begin{array}{l}\text { Study } \\
\text { abroad } \\
\text { group }\end{array}$} & \multirow{2}{*}{$\begin{array}{l}\text { Control } \\
\text { group }\end{array}$} & \multicolumn{2}{|c|}{ t-test } \\
\hline & & & & $\mathbf{t}$ & p-val. \\
\hline \multirow[t]{2}{*}{ Age } & Unmatched & 22.81 & 23.64 & $\begin{array}{l}-3.42 \\
0\end{array}$ & $<.01$ \\
\hline & Matched & 22.89 & 22.81 & & .78 \\
\hline Gender: & Unmatched & .36 & .38 & -.33 & .74 \\
\hline Female $=0$, Male $=1$ & Matched & .33 & .51 & -2.71 & $<.01$ \\
\hline \multicolumn{6}{|l|}{ Multicult.background } \\
\hline \multirow{2}{*}{$\begin{array}{l}\text { Parents nationality: } \\
\text { (same }=0 \text {, different }=1 \text { ) }\end{array}$} & Unmatched & .07 & .02 & 1.80 & .07 \\
\hline & Matched & .03 & .00 & 1.75 & .08 \\
\hline \multirow[t]{2}{*}{ Foreign languages spoken } & Unmatched & 2.21 & 1.62 & 6.14 & $<.00$ \\
\hline & Matched & 2.08 & 1.92 & 1.75 & .08 \\
\hline \multirow{2}{*}{$\begin{array}{l}\text { Frequency of travelling } \\
\text { abroad past } 12 \mathrm{mo} .\end{array}$} & Unmatched & 3.39 & 2.54 & 7.01 & $<.00$ \\
\hline & Matched & 3.29 & 3.39 & -.83 & .41 \\
\hline \multirow{2}{*}{$\begin{array}{l}\text { Lived abroad previously } \\
(\mathrm{No}=0, \mathrm{Yes}=1\end{array}$} & Unmatched & .49 & .45 & .07 & .48 \\
\hline & Matched & .48 & .58 & -1.46 & .15 \\
\hline \multirow{2}{*}{$\begin{array}{l}\text { Contact with international } \\
\text { students at wave } 1\end{array}$} & Unmatched & 3.18 & 2.74 & 2.35 & .02 \\
\hline & Matched & 3.11 & 3.04 & .33 & .74 \\
\hline \multicolumn{6}{|l|}{ Political background } \\
\hline \multirow[t]{2}{*}{ GAL-TAN ideology } & Unmatched & 2.96 & 2.84 & .50 & .61 \\
\hline & Matched & 2.95 & 2.66 & 1.27 & .21 \\
\hline \multirow[t]{2}{*}{ Left-right ideology } & Unmatched & 3.90 & 3.85 & .25 & .80 \\
\hline & Matched & 3.80 & 3.36 & 2.46 & .02 \\
\hline \multirow[t]{4}{*}{ European identity index } & Unmatched & 3.87 & 3.59 & 2.45 & .02 \\
\hline & Matched & 3.79 & 3.87 & -.72 & .47 \\
\hline & N unmatched & 168 & 98 & & \\
\hline & $\mathrm{N}$ matched & 114 & 98 & & \\
\hline
\end{tabular}

Note: (1) Non-parametric combinations (NPC) testing led to a rejection of the sharp null hypothesis of no difference between study abroad and control group ( $\mathrm{p}<.00$; conducted in R using the NPC function programmed by Caughey, Dafoe, and Seawright, 2014). I conducted a matching analysis to check the robustness of results when controlling for imbalances between treatment and control group. (2) The matching analysis that produced the samples above was conducted based on two term study abroad group and control group. 
Table A14. European identity: change and stability.

\begin{tabular}{|c|c|c|c|c|c|}
\hline & Wave 1 & Wave 2 & Wave 3 & $\begin{array}{l}\Delta \mathrm{w} 1-\mathrm{w} 2 \\
(\mathrm{SE})\end{array}$ & $\begin{array}{l}\Delta \mathrm{w} 2-\mathrm{w} 3 \\
(\mathrm{SE})\end{array}$ \\
\hline $\begin{array}{l}\text { Study abroad } \\
\text { group } \\
N=257\end{array}$ & $\begin{array}{l}3.75 \\
(.94)\end{array}$ & $\begin{array}{l}3.94 \\
(.95)\end{array}$ & $\begin{array}{l}3.96 \\
(.97)\end{array}$ & $\begin{array}{l}.19^{* \star \star} \\
(.05)\end{array}$ & $\begin{array}{l}-.0 .2 \\
(.04)\end{array}$ \\
\hline $\begin{array}{l}\text { Control group } \\
N=69\end{array}$ & $\begin{array}{l}3.61 \\
(.98)\end{array}$ & $\begin{array}{l}3.50 \\
(1.07)\end{array}$ & $\begin{array}{l}3.58 \\
(1.01)\end{array}$ & $\begin{array}{l}-0.11 \\
(.09)\end{array}$ & $\begin{array}{l}.08 \\
(.09)\end{array}$ \\
\hline
\end{tabular}

${ }^{* * *} p<.001$, two tailed significance test; based on respondents who went abroad between wave 1 and wave 2 and who answered all waves of the panel survey. Standard errors in parentheses 
Table A15. Question wording of European identity measures

\begin{tabular}{|c|c|c|}
\hline Item & Question wording & Scale \\
\hline \multicolumn{3}{|l|}{ Dependent variable } \\
\hline EU citizenship & $\begin{array}{l}\text { How frequently do think of yourself as an EU } \\
\text { citizen? }\end{array}$ & $\begin{array}{l}0 \text { (not at all) to } \\
6 \text { (very often) }\end{array}$ \\
\hline EU attachment & $\begin{array}{l}\text { People may feel different levels of attachment } \\
\text { towards different geographical areas. How } \\
\text { attached do you feel to Europe? }\end{array}$ & $0-6$ \\
\hline Closeness & How close do you feel to other Europeans? & $0-6$ \\
\hline Pride & Are you proud of being European? & $0-6$ \\
\hline Commonalities & $\begin{array}{l}\text { To what extent do you think you have } \\
\text { something in common with other Europeans? }\end{array}$ & $0-6$ \\
\hline EU identity index & $\begin{array}{l}\text { Additive index based on the five items above } \\
\text { Cronach's alpha is } 0.79 \text { at wave } 1,0.81 \text { at } \\
\text { wave } 2 \text {, and } 0.79 \text { at wave } 3\end{array}$ & $0-6$ \\
\hline \multicolumn{3}{|l|}{ Independent variables } \\
\hline & $\begin{array}{l}\text { This part is about your daily interaction with } \\
\text { international students, i.e. students from other } \\
\text { countries. }\end{array}$ & \\
\hline $\begin{array}{l}\text { Contact with } \\
\text { internationals (socializing) }\end{array}$ & $\begin{array}{l}\text { How frequently do you interact with } \\
\text { international students in general? }\end{array}$ & $\begin{array}{l}0 \text { (not at all) to } \\
6 \text { (very often) }\end{array}$ \\
\hline $\begin{array}{l}\text { Contact with } \\
\text { internationals (personal) }\end{array}$ & $\begin{array}{l}\text { How often do you discuss personal problems } \\
\text { with international students? }\end{array}$ & $0-6$ \\
\hline $\begin{array}{l}\text { Contact with } \\
\text { internationals (academic) }\end{array}$ & $\begin{array}{l}\text { How often do you discuss academic affairs } \\
\text { with international students? }\end{array}$ & $0-6$ \\
\hline \multirow[t]{2}{*}{$\begin{array}{l}\text { Contact with hosts } \\
\text { (socializing) }\end{array}$} & $\begin{array}{l}\text { This part is about your interaction with students } \\
\text { who are at home in the country where you are } \\
\text { spending your study abroad period. Students } \\
\text { from other countries or other Erasmus students } \\
\text { should not play a role here. }\end{array}$ & \\
\hline & $\begin{array}{l}\text { How frequently do you interact with students } \\
\text { who are at home in your host country in } \\
\text { general? }\end{array}$ & $\begin{array}{l}0 \text { (not at all) to } \\
6 \text { (very often) }\end{array}$ \\
\hline $\begin{array}{l}\text { Contact with hosts } \\
\text { (personal) }\end{array}$ & $\begin{array}{l}\text { How often do you talk about personal problems } \\
\text { with students who are at home in your host } \\
\text { country? }\end{array}$ & $0-6$ \\
\hline $\begin{array}{l}\text { Contact with hosts } \\
\text { (academic) }\end{array}$ & $\begin{array}{l}\text { How often do you talk about academic affairs } \\
\text { with students who are at home in you host } \\
\text { country? }\end{array}$ & $0-6$ \\
\hline $\begin{array}{l}\text { Satisfaction w/ study } \\
\text { abroad }\end{array}$ & $\begin{array}{l}\text { All things considered, how satisfied are you } \\
\text { with your study abroad? }\end{array}$ & $0-6$ \\
\hline Ease of adaption & $\begin{array}{l}\text { Did you find it difficult to get used to your new } \\
\text { environment? }\end{array}$ & $0-6$ \\
\hline Home sickness & $\begin{array}{l}\text { Did you feel home sick during your time } \\
\text { abroad? }\end{array}$ & $0-6$ \\
\hline lived abroad & $\begin{array}{l}\text { Did you ever live abroad before your study } \\
\text { abroad? }\end{array}$ & $\begin{array}{l}0=\text { no } \\
1=2-6 \text { months } \\
2=7-12 \text { months } \\
3=\text { more than a } \\
\text { year }\end{array}$ \\
\hline
\end{tabular}


frequency of travelling

Foreign language competence

Parents nationality

GAL-TAN ideology

Left-right ideology

Reasons for students to study abroad / Non-cosmopolitan dummy
How often did you travel to another country within the past 12 months?

How many other languages do you speak besides your mother tongue, i.e. in how many other languages can you take part in a conversation?

Do your parents have the same nationality?

Some people consider themselves progressive or liberal, others rather see themselves as conservative. People who consider themselves progressive or liberal tend to favor an expansion of personal liberties, for example when it comes to abortion or same sex marriages. People who consider themselves conservative tend to favor a traditional notion of order, family and in regard to values.

On a scale from 0 to 10 , where would you see yourself? 0 means progressive or liberal views and 10 conservative views.

In politics, people sometimes talk about left and right. On a left-right scale where 0 means left and 10 means right, where would you place yourself?

To what extent do you consider the following considerations part of your motivation to study abroad. See all answer categories in Table A6. You can select up to three reasons.

$0-10$
$0=$ not

$1=1-2$ times

$2=3-4$ times

$3=5-6$ times

$4=7$ or more

[number]

$0=$ same

$1=$ different

Note: The survey was administered in German; tenses were adjusted to situation/location of respondent. 
Table A16. Reasons for students to study abroad

Professional advancement

Gain an advantage on the job market

$45 \%$

To learn a specific skill

$32 \%$

Acquire a specific certificate abroad

$9 \%$

Cosmopolitan reasons

Get a better understanding of another country

To travel

$50 \%$

To see my own country from a different perspective

Ambiguous/other

Improve my foreign language competence

$82 \%$

Find out what I want to do with my life

It is a compulsory part of my curriculum

$15 \%$

Open field remark

$8 \%$

Because a friend also participates in a study abroad

$4 \%$

Note: Participants could select up to three reasons simultaneously. 
Table A17. Robustness check: Social interactions and European Identity (while abroad)

Model 1

Model 2

Model 3

\begin{tabular}{|c|c|c|c|}
\hline Contact $\mathrm{w} /$ international students & $\begin{array}{l}0.11^{* *} \\
(0.04)\end{array}$ & $\begin{array}{l}0.11^{*} \\
(0.04)\end{array}$ & $\begin{array}{c}0.30 \\
(0.16)\end{array}$ \\
\hline Contact $w /$ internationals*pre-EU ID & & & $\begin{array}{l}-0.05 \\
(0.04)\end{array}$ \\
\hline Contact $w /$ host country students & $\begin{array}{c}0.06 \\
(0.04)\end{array}$ & $\begin{array}{c}0.06 \\
(0.04)\end{array}$ & $\begin{array}{c}0.02 \\
(0.06)\end{array}$ \\
\hline Contact w/ hosts*pre-EU ID & & & $\begin{array}{l}-0.02 \\
(0.02)\end{array}$ \\
\hline age & & $\begin{array}{c}0.03 \\
(0.04)\end{array}$ & $\begin{array}{c}0.04 \\
(0.04)\end{array}$ \\
\hline sex & & $\begin{array}{c}0.08 \\
(0.13)\end{array}$ & $\begin{array}{c}0.08 \\
(0.13)\end{array}$ \\
\hline lived abroad & & $\begin{array}{c}0.00 \\
(0.13)\end{array}$ & $\begin{array}{c}0.00 \\
(0.13)\end{array}$ \\
\hline frequency of travelling & & $\begin{array}{c}0.05 \\
(0.07)\end{array}$ & $\begin{array}{c}0.05 \\
(0.07)\end{array}$ \\
\hline Foreign language competence & & $\begin{array}{l}-0.07 \\
(0.09)\end{array}$ & $\begin{array}{l}-0.07 \\
(0.09)\end{array}$ \\
\hline Parents nationality & & $\begin{array}{l}-0.02 \\
(0.23)\end{array}$ & $\begin{array}{l}-0.03 \\
(0.23)\end{array}$ \\
\hline Non-cosmopolitan & & $\begin{array}{c}0.23 \\
(0.26)\end{array}$ & $\begin{array}{c}0.27 \\
(0.25)\end{array}$ \\
\hline European identity before going abroad $\left(Y_{\mathrm{t}-1}\right)$ & $\begin{array}{c}0.75^{\star * *} \\
(0.07)\end{array}$ & $\begin{array}{c}0.76^{* * *} \\
(0.07)\end{array}$ & $\begin{array}{c}0.95^{\star * \star} \\
(0.24)\end{array}$ \\
\hline Constant & $\begin{array}{c}0.33 \\
(0.35)\end{array}$ & $\begin{array}{l}-0.43 \\
(1.06)\end{array}$ & $\begin{array}{l}-1.45 \\
(1.46)\end{array}$ \\
\hline Adjusted $\mathrm{R}^{2}$ & 0.54 & 0.53 & 0.53 \\
\hline N & 124 & 124 & 124 \\
\hline
\end{tabular}




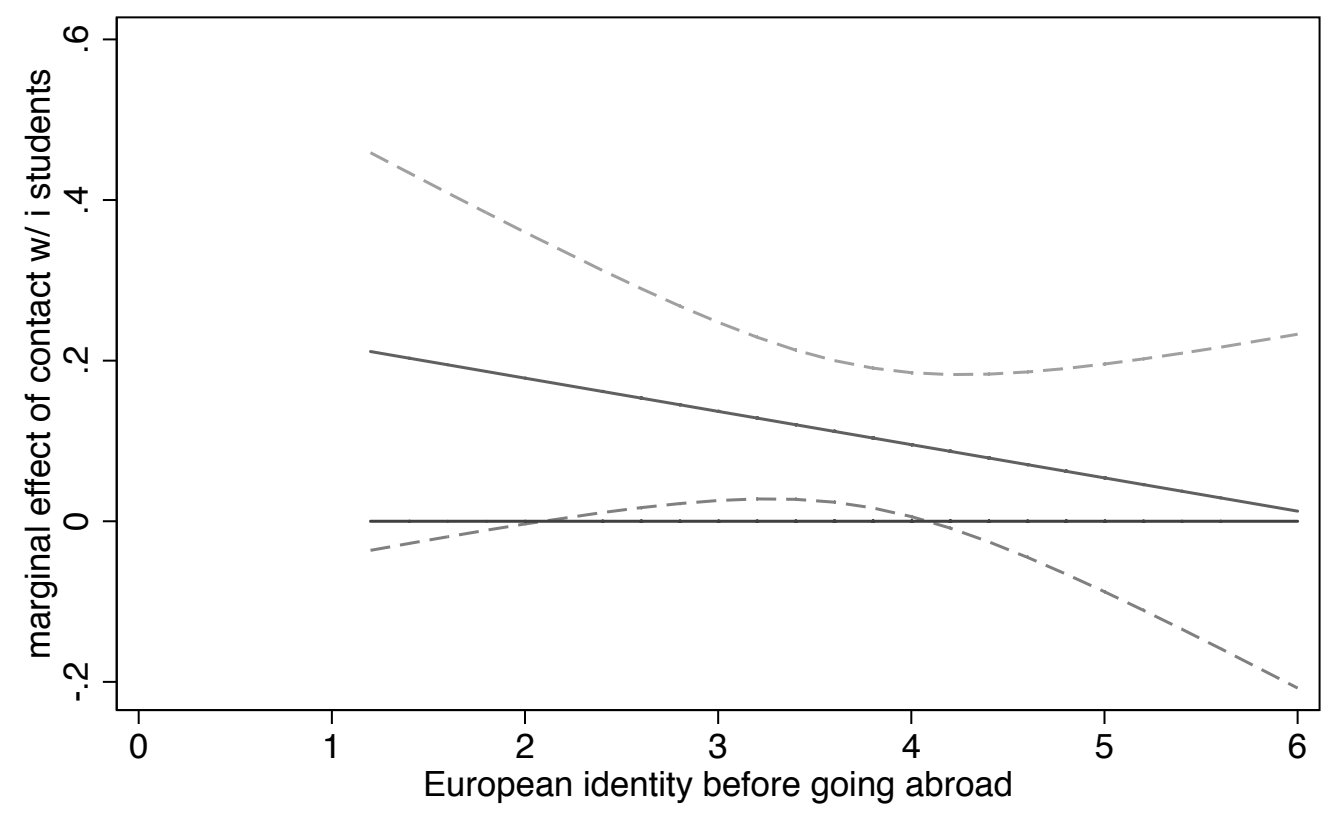

Figure A1. Marginal effect of contact with international students

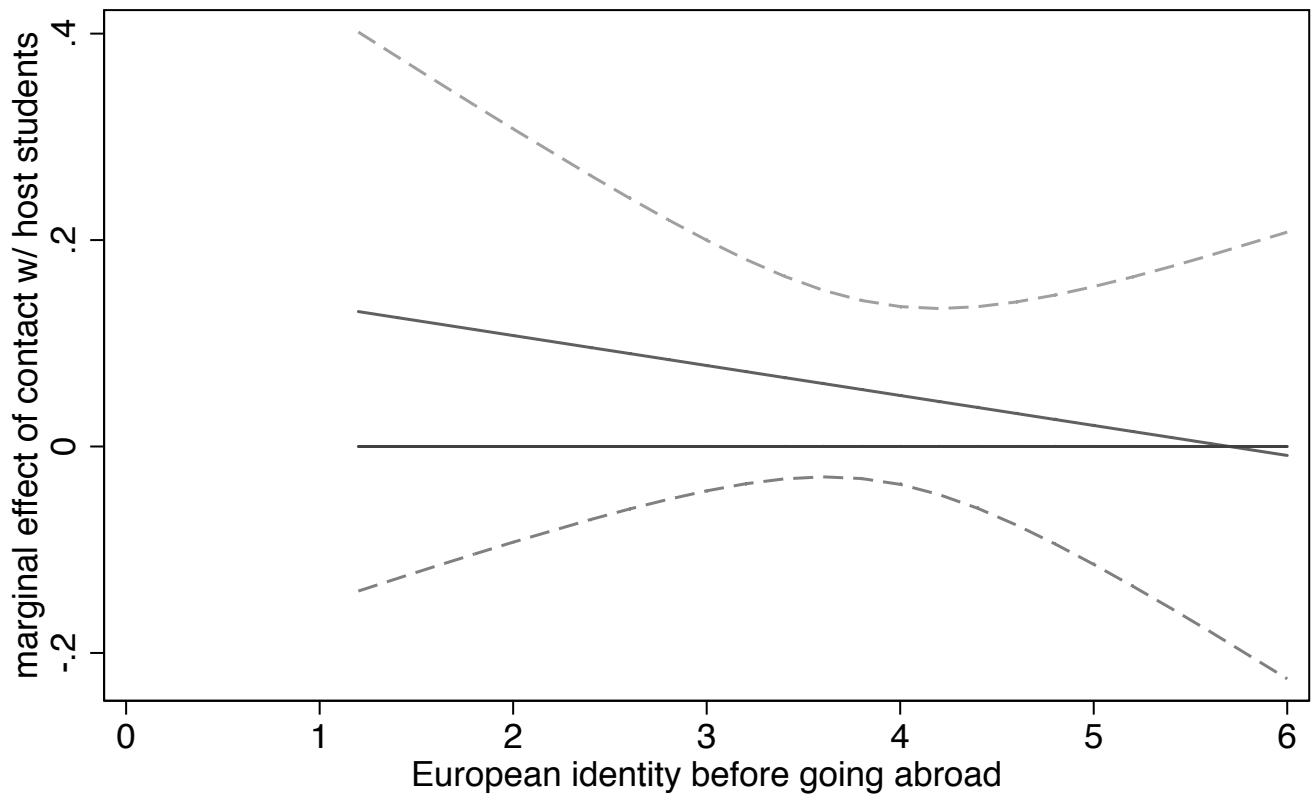

Figure A2. Marginal effect of contact with international students 